\title{
A Comparative Study of Contemporary Ceramic Sculptures between China and Bangladesh
}

\author{
Md. Anisul Haque a,1,* \\ ${ }^{a}$ Nanjing University of the Arts, School of International Education, No.74, Beijing West Road, Gulou District, Nanjing, 210013, P. R. China \\ 1 anis_cedu@yahoo.com \\ * corresponding author
}

\section{ARTICLE INFO}

\section{Article history}

Received 2020-06-07

Revised 2020-06-11

Accepted 2020-06-20

Keywords

Contemporary Ceramic Sculpture

China Ceramic

Bangladeshi Ceramic

Chinese Sculptor

Bangladeshi Sculptor

\section{ABSTRACT}

Today, contemporary ceramic sculpture expressions come in various forms. Ceramic sculpture is also a medium to express ideas and creative imagination for ceramic artists. This research paper presents a comparative discussion of Contemporary Ceramic Sculptures between China and Bangladesh, which aims to promote the further development of ceramic sculpture through exchanges of ceramic culture. This research not only analyzes contemporary ceramic sculptures between China and Bangladesh but also learns about the economic, cultural, and social influences of the two countries for the development of global ceramic sculptures. Two countries review the history of ceramics and talk about the specificities in the field of ceramics. This study aims to reveal the development of ceramic sculptures between the two countries so that this research can find out how contemporary ceramic artists in China and Bangladesh created unique and themed ceramics. How modern ceramic sculpture influence by philosophy, culture, tradition, and material effect. The combination of modern china and Bangladeshi ceramic sculpture is so touching and unique. The conclusion of this research is through various experiments and creative learning of ceramic sculptors, making the structure of knowledge of modern ceramic artists become formed. As a result, artistic concepts have become more diverse, and the two countries, Bangladesh and China, can exchange ideas in the creation of ceramic sculptures.

This is an open-access article under the CC-BY-SA license.

\section{Introduction}

The sculpture is the physical representation of cultures' views, beliefs, and practices. The statue has long held a place of importance in Bangladeshi culture. The art of Sculpture in Bangladesh began with the formation of Terracotta, which can use silt (a type of clay) [1]. Terracotta art is prevalent in Bangladesh. About 2,500 years ago, during the Ancient period, Parra and Senna empires sculpture began and flourished. Most of the statues found in Bangladesh are made of Terracotta, bronze, and black stone [2]. In the ceramic art of Bangladesh, there are lovingly object's art, folk dolls, utility vessels for the ordinary shop, terracotta narrative tiles made on big commissions, and various kinds of holy icons of both Hindus and Muslims [3]. The sculpture created after Independence in Bangladesh has been able to give a new look. The contemporary ceramic sculptor is one of the holders and carriers of our country's culture [4]. In the field of ceramics, Chinese ceramics occupy the best position in the world. In the 21st century, Chinese art is moving forward [5]. In particular, Chinese porcelain artworks are famous all over the world. Today is china's ceramic creation is developing along with the development of the contemporary art movement [6].

In contemporary sculpture, content is given prominence to making sculpture whatever which material artists used. Contemporary art has been an international communication as well as a weapon 
for the formation of society [7]. Some of the modern ceramic sculptural works shake up the values of society. Ceramic sculpture is a three-dimensional art form where clay fired at specific temperatures [8]. Contemporary ceramic sculptures explore highly individualized emotions, such as the problem of the analytic philosophy of art [9]. In the contemporary art world, ceramic sculpture occupied its position. The essential difference between modern and modern ceramic sculptures is the period. Particularly modern sculpture expanded between the late 19th and late 20th centuries. We can say after the 1960s to still emerging contemporary ceramic sculptures [10]. Modern ceramic sculptures art style is different trends and movements where describes abstract expressionism, characteristic for the traditional arts. Contemporary ceramic sculpture style is dynamic, literally produced more experimental works, and it is always changing [11]. It is disclosing social, economic, political issues.

Compared to China, the ceramic Sculpture of Bangladesh is a little bit behind for the lack of economic and government patronage. However, Bangladeshi ceramic sculptures art has begun to take on a unique artistic orientation through the personal initiative of some contemporary artists. So in this research, we want to use the advanced technology of China and world-famous Chinese porcelain to combine Bangladeshi art philosophy with self-concept to create unique ceramic arts. This study serves to determine the cultural impact of the two countries, Bangladesh and China, on the development of contemporary ceramic sculptures. This research topic uses a new perspective on ceramic art, promotes friendship between young artists of the two countries, as well as an effort to improve diplomatic relations between China and Bangladesh. This study can play an essential role in the development of ceramic exchanges between Bangladesh and China in the future.

\section{Method}

Every country in the world looks for its traditions and culture. This study tries to see the development of traditional ceramics and focuses on the use of technology in improving the Bangladeshi art of ceramics. In Bangladesh, it is challenging to collect porcelain soil. To date, this study has not found a famous artist from Bangladesh who used porcelain to make ceramic sculptures. Moreover, the highest temperature burned above $1200{ }^{\circ} \mathrm{C}$. We cannot talk about ceramic art without talking about Chinese ceramic art. Reaching back to history (221-206) B.C. terracotta warriors is an essential aspect of the Chinese ceramic sculpture [12]. This artwork proves that makes ceramic sculptures at that time; the Chinese acquired considerable skill. Chinese sculpture has made an essential contribution to the practicing of ceramic sculpture and glaze. Humans have created various types of pottery and ceramics that are inspired by the spirit of creativity and beauty. According to Vandiver, ceramics are the oldest art in human history [13]. According to anthropologists, it originated in the Neolithic period [14]. Under this continuity, art media in Bangladesh has received the first aesthetic in the hands of traditional pottery.

Contemporary ceramic sculpture is a popular art today. The process of making ceramic sculptures is very different from other art media because after a ceramic artist succeeds in forming a ceramic sculpture, a ceramic artist must burn it at a specific temperature. Contemporary ceramic sculpture as a visual art helped create the artistic development of ceramics on a global scale [15]. Even for this purpose, developing postmodern concepts to build the aesthetics of contemporary ceramic sculptures is becoming a trend. One of them uses clay to produce ceramic sculptures because the character of the material is quite good and can last more [16]; that is why contemporary ceramic sculpture is perhaps the most comprehensive spread type of sculpture in the present day. In our society, the contemporary sculpture reflects current intention and modern thoughts. The several types of considerations in making ceramic sculptures are the selection of materials, techniques, temperatures, determining the shape and concept. Ceramic artists in creating ceramic sculptures also get influence from the surrounding social conditions, such as their own culture, traditions, and philosophical matters [17]. Comparing contemporary ceramic sculptures between China and Bangladesh thus needs to base several characters. This study attempts to highlight these similarities and differences. Notably, whether aesthetic, cultural, material, and philosophical influences Chinese and Bangladeshi ceramic artists.

\section{Results and Discussion}

The ceramic sculpture has a profound relationship with chemistry [18]. If we look back at the past of ceramics, as a result of numerous experiments, the ceramic art is continually evolving. Moreover, 
by maintaining the trend, contemporary ceramic artists have achieved great success. Modern ceramic artists are working to accelerate contemporary art learning around the world in their skills. At present, the significant contribution of contemporary ceramic artists to contemporary ceramic artwork is in the matter of material mixing techniques. This study considers if the gift of ceramic artists to contemporary ceramic art is their process of exploiting ceramic sculptures by using an aesthetic design approach.

\subsection{Summary of the History of Ceramic Sculpture in China}

Chinese ceramic art began to improve since the Neolithic period. The history of Chinese ceramics can be traced back to over ten thousand years ago. The Han Dynasty (206 B.C.E. -220 C.E.) is famous for Classic Chinese reddish-orange terracotta dancing figures. These two figure man and women call Sichuan pottery or a traditional style of the Han dynasty [19]. Chinese antique earthenware dancing sculpture keeps an excellent example of Han dynasty ceramic sculpture. The woman wearing a tripartite floral headdress and man wearing a curved helmet, both with raised their right arms and both wearing floor-length robes. The Chinese ceramic sculpture is known to the outside world during the Tang Dynasty (618-906) C.E [20]. Tang horses are among the most famous sculptures of ancient Chinese civilization. Especially "three-colored" low fired those charming horses. The horse can be seen in Figure 1.

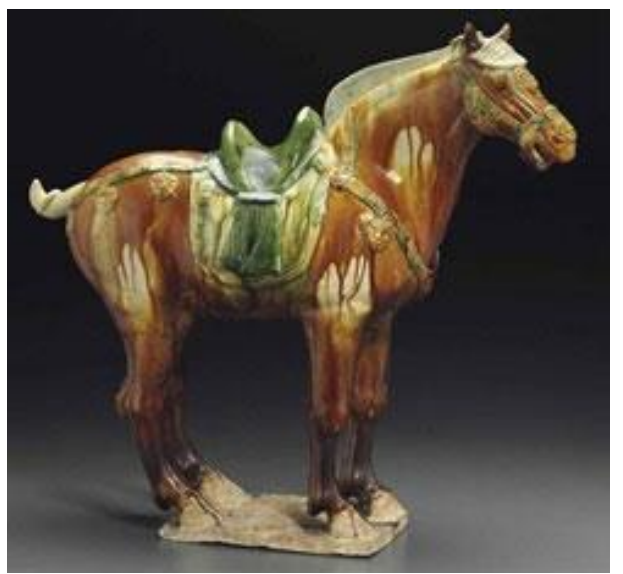

Fig. 1. Tang horses, “three-colored."

In China, the horse was the symbol of property and power [21]. Ceramic artists also produce several camel statues. This icon has a soft glass color and pattern. Build sculptures of this period more practicing realistic. Proportionally Tang dynasty ceramic sculptures showed accurate measurement [22]. Tang dynasty figures can be considered unique features for their excitant style. In this time, sculptures influence from Europe, the middle east, India, Mongolia. This period builds many Buddhist sculptures for that during the Tang dynasty, Buddhist art in china fully grown. Tang artist also made extraordinary fantastic earthenware glazed animals. They used cobalt blue, and it was more valuable than gold. Porcelain originated during the Tang dynasty [23]. It was created by mixing clay with quartz and the mineral feldspar to make a hard. The western world introduced porcelain through silk rod. Jingdezhen is the capital of porcelain [24]. During the Song dynasty (960-1279), C.E. Chinese ceramics are one step further. The main attraction of the Song dynasty ceramic sculpture is a kind of monochrome porcelain called celadon [25]. Celadon is a type of porcelain with translucent glaze or opaque green glaze [26]. A good example is the Buddha ceramic statue, where ceramic artists use celadon glaze. Ceramic artists during the Song Dynasty made ceramic sculptures in various forms for imperial purposes and religious functions.

Next, comes the Yuan Dynasty (1271-1368) C.E. China was under Mongol rule. During this period, Jingdezhen became more critical for blue and white porcelain. China, at that time, reveals influence from Mongol art [27]. Yuan sculptures combined the expression of Chinese and Mongolian art [28]. During the Yuan Dynasty, people specifically made the Shufu porcelain ceramic ware and sculptures [29]. A very opaque glaze is wholly used in Shufu porcelain. However, Shufu porcelains were used for making tableware items such as plates, bowls. In China (1368-1644) C.E. Ming Dynasty has become well-known around the world for the unique quality of its ceramic art. During this period, ceramic art gains excellent condition, especially for cobalt blue and white porcelain [30]. That is a 
time when sea-green celadon glazed stoneware ceramic was also produced. Artists created small figurines of the gods, as well as various forms of sculptures. The Ming period exported porcelain around the world on a beautiful level [31]. During the Qing Dynasty (1644-1912) C.E., we see different type's porcelain styles. This period began to produced bright colors of ceramic sculptures. They were especially developing five-colored figurative Ceramic Sculpture. One of the most significant technical contributions made to ceramics during the Qing period is fencai (粉彩) enamel [32]. Qing dynasty ceramic sculptures have the characteristics of humanistic, regional, and national [33]. This period ceramic sculptures can be classified into five categories: human, animal, utensil, mini-sculpture, and tile ride sculpture [34]. The republic of china 1912 to 1949 ceramic sculptures continues improving. No other country in the world has spread like Chinese ceramic art has maintained by the People's Republic of China.

\subsection{Summary of the History of Ceramic Sculptures in Bangladesh}

The contribution of ceramics sculptures is unforgettable in the history of art in Bangladesh. Alluvium clay is abundant in Bangladesh, the main reason many rivers. Among the antiquities and artifacts that have been discovered in Bangladesh, most of the ceramic art is occupied. Almost all the northwestern and central parts of Bangladesh have found pottery and terracotta sculptures. The art of sculpture began and flourished about 2500 years ago in ancient Bengal [35]. Excavations carried out in Mohasthangarh, Bogra managed to find a unique earthenware statue (300BC), researchers compared the findings of the pottery sculpture with ancient figures of the civilizations of Mahengodaro and Harappa. Initially, the ceramic sculptures we see at that time were mostly made for the temple [36]. The artistic intention of Bengali artists found expression in clay, which was abundantly available, and it hardly involved ceramic sculptures [37]. Thousands of ignorant artists produced many terracotta objects from pre-historic times. The abundant finds of objects made of Terracotta in Bengal are a sure evidence of the use of clay as the most common and accessible medium of artistic expression of the people from the very dawn of civilization in this deltaic land [38].

During the Mauryan Empire (321BC-183BC), clay sculptures have been dominated by Buddhist temples. The history of Bengal is intertwined with the history of the broader Indian subcontinent and the surrounding regions of South Asia and Southeast Asia [39]. The concept of religious sculpture was also predominant during the Mauryan Empire [40]. The influence on sculpture was mainly due to Ashoka's conversion to Buddhism. Terracotta Gods and Goddesses have accompanied these notable structures. The Mauryan sculptures exude a unique, earthy appeal. Such terracotta objects have been traced in the area extending from Pataliputra to Taxila. That is, time sculptures reflected an influence of the spirit of the style of the Persian and Hellenistic Sculpture. The majority of sculptures that are so beautiful have extraordinary structural decoration, shapes made with professional, and stylish appearance. The statues of the Mauryan Empire, seen in Figure 2, include art forms created during this period and are well-known specimens of the Mauryan Art.

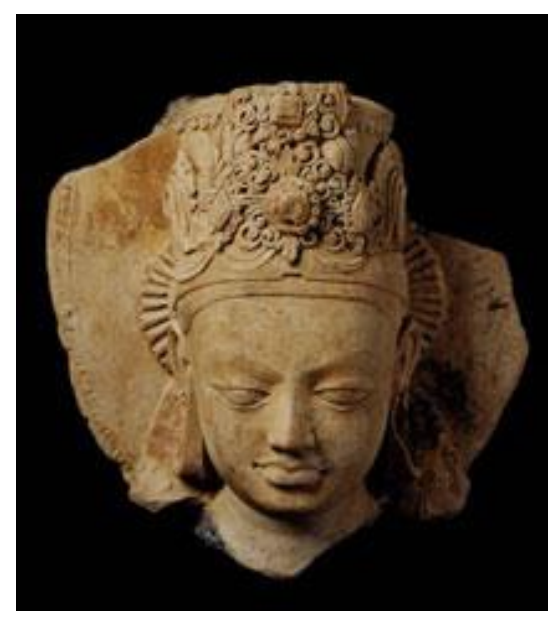

Fig. 2. Mauryan Sculpture

Approximately 4th to 6th century, during The Gupta period In Bangladesh, ceramic sculptures development is the perfect balance and harmony of all elements in style and iconography. The ornamentation is heavy and unusual; the hair is long and worn in a variety of styles, one of the most 
significant contributions made to ceramics sculptures during the Gupta period [2]. The success of Gupta sculpture lies in its attaining a balance between the sensuousness of the Kushan figures and the symbolic abstraction of the early medieval ones. Between the 8th to 12th centuries, The Pala period is regarded as one of Bengal's golden ages. It was the largest Bengali empire that was known to ancient and classical India. Pala Sculpture derived its origin from the late Gupta style. According to the national museum of Bangladesh, most Pala sculptures representing Buddhist gods and goddesses [41]. Pala sculpture began as a natural and straightforward sense of religious experience. Pala sculptures face expression with an apparent repose of meditation [42]. During the 1097-1223 AD Sena period, most of the ceramic sculptures made for the Hindu religion. The specialty of Sena period sculpture is technical perfection and physical charm [43]. A large number of sculptures representing Hindu gods and goddesses belong to the phase of artistic activity initiated under the Sena rulers. 13th century to the 16th century Mughal Empire established Islamic rulers in Bengal. A considerable influence of Islamic art in Bangladesh mostly flourished during this time [44]. No such ceramic sculptures were made this time.

However, particular importance has been given to horses and elephants in the art at that time. Moreover, make folk style ceramic horses and elephants. The British period (1700-1947) C Bengal ceramic sculpture influence by classical west style [45]. Rayer Bazaar was founded during the colonial period, most probably in the 19th century. It was the potters who first started to live here beside the Turag River. The Pakistani period, c. 1947-1971, we cannot be seen any improvement development in the field of ceramic sculptures. However, in Bengal's most common and accessible medium of art expression is terracotta sculptures still decorating Bengal art. The ceramic sculptures created after the independence of Bangladesh are known as modern sculptures. 1961 began institutionally practice ceramic sculptures, technically one step ahead [46].

\subsection{Contemporary Chinese Ceramic Sculpture}

China was relatively isolated from cultural-artistic developments in other parts of the world. Over the last century, China has experienced unprecedented cultural change. Chinese Contemporary Art starts from the end of the Cultural Revolution [47]. Around 1979, Chinese artists were suddenly exposed to western art history, which led to a rapid turnover of artistic styles. Contemporary Chinese ceramic sculpture is making a tremendous reborn in the world of ceramic sculptures. In the twentieth century, realism in China has been limited to the practice of ritual art [48]. For many years, China could not find a way out of the metaphorical sense of contemporary art because of its social and personal philosophy [49]. The far-reaching thoughts and creative practices of today's Chinese artists help modernize modern China ceramic sculptures. At the beginning of the twenty-first century, China started to organize international art activities, especially ceramic symposiums, workshops, art fairs, making a way to exchanges between local and international artists' creativity. This is why Chinese artists working today are interested in issues connected to contemporary art.

It is said that one of the indispensable elements of contemporary art is subject matter or theme. I think the price difference between Chinese and other countries' contemporary ceramic sculptures is aesthetic beauty. Contemporary Chinese ceramic sculpture profoundly influences by Chinese tradition and culture [50]. Nowadays, the modern ceramic artist is in china, making artworks artist's personal feelings, shaping it a creative sculpture rather than the traditional craft. Chinese contemporary ceramic sculptures became various developing patterns and grown a new scene since. Perhaps Chinese contemporary ceramic sculptures transitions make the unique possibilities that no other culture has. Thousands of years of China's history and culture blend in with Chinese traditions in a way for greatly influence the view of contemporary Chinese artists. The socialist system of China has considerable influence on the opinions of Chinese artists [51], where contemporary ceramic artists produced culturally strong and unique art pieces. Therefore contemporary Chinese ceramic sculptors are becoming renowned in the world. As a result, contemporary Chinese contemporary ceramic sculpture art is moving towards aesthetic improvement very quickly as like the Chinese economy.

\subsection{Contemporary Bangladeshi Ceramic Sculpture}

After independence from Pakistan, in Bangladesh country brought with it the new hope for a secular, democratic, socialist state where Bangladeshi culture would gain. The liberation war renewed in contemporary arts the search for inspiration from Bengali cultural heritage. In Bangladesh, most of the modern terracotta sculpture and relief artworks have been dominated by the liberation war. Contemporary ceramic sculpture is making a great revival in Bangladesh of fine arts. After birth, 
Bangladesh built relations with the world and art education. Contacts grew with Europe, America, India, Japan, and China, bringing further change in ceramic art. Now the development of ceramics in Bangladesh is in a state of imbalance as the medium of ceramic Sculpture in Bangladesh could not make a good position as other mediums did on art. However, some of the ceramic artists continue working with ceramic sculptures for developing Bangladeshi ceramic art. Bangladesh ceramic artists transform stoneware and earthenware clay into various forms of ceramic sculpture.

The new pattern of Bangladeshi contemporary ceramic sculptures development shows the construction of the advancement of modern ceramic form. Few ceramic artists show a deepening of cognition of ceramic aesthetic value and cultural value. Bangladeshi contemporary ceramic artists reflect modern ideas and thought, which are subject to implement the changes in society. Contemporary Bangladeshi ceramic sculpture is both sympathetic to the cultural and historical frameworks within which it is produced but also clearly attuned to the global networks and internationally.

\subsection{Chinese Contemporary Ceramic Sculptors and their Artworks}

\subsubsection{Zhou Guo Zhen}

Zhou Guzheng is a contemporary ceramic sculpture artist as well as professor and honorary director of the fine arts department at the Jingdezhen ceramic institute. Zhou Guzheng was born in Renxian, Hunan province, in 1931. He is a ceramic artist, a painter, and a ceramic art educator who has been working for over 50 years in the field of clay and fire. Among the ceramic artist of this time, his contemporary ceramic sculptures completely different. In China, he has composed his unique ceramic sculptures; one of them can be seen in Figure 3, and besides that, his 'animal world' sculptures can be found in addition to variations of glazes, as well as variations of tradition.

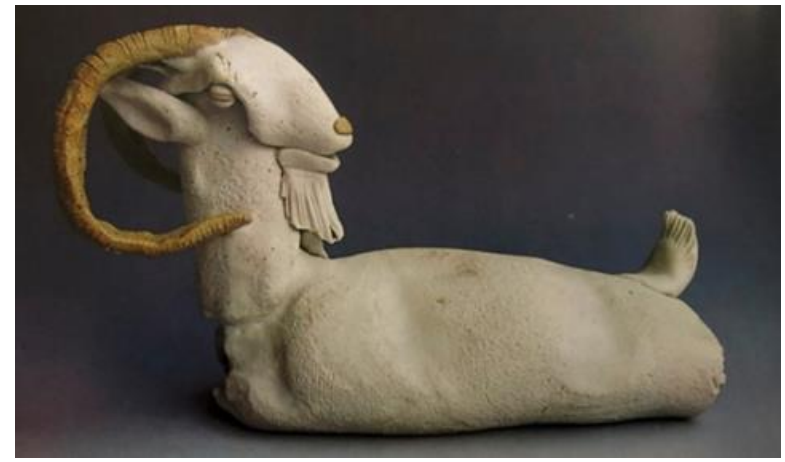

Fig. 3. Artist Zhou Guo Zhen's Sculpture

\subsubsection{Chen Songxian}

Artist Chen Songxian born in 1941, his hometown is Shangyu, Zhejiang province. He is now a professor of china's fine arts academy. Chen Songxian is an experimental ceramic artist who has a penchant for experimenting with fire and glaze. He never forces clay to make unique artworks. Chen Songxian never insisted on using clay to make art. Chen Songxian believes that Buddhists must put clay as a base in making sculptures, and must have a good understanding of the clay. According to Chen, clay must be an artistic medium in creating a distinctive religious aesthetic. Figure 4 is a sculpture by Artist Chen Song Xian.

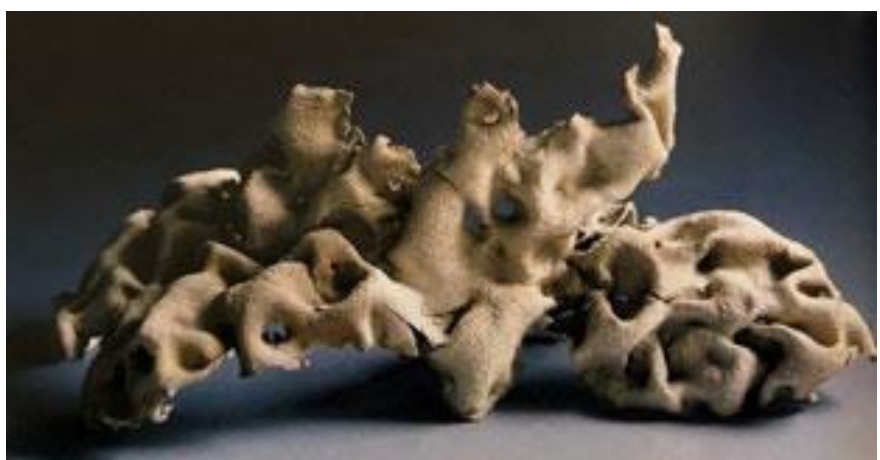

Fig. 4. Artist Chen Song Xian's Sculpture 


\subsubsection{Yao Yong Kang}

World-famous ceramic sculptor Yao Yong Kang was born in 1942 in Ningbo, Zhejiang Province, China. He works as a professor and postgraduate tutor in the Jingdezhen ceramics academy. Extraordinarily talented and exceptional ceramic artist Yao Yong Kang creates contemporary, traditional characteristics styles ceramic sculptures. The beauty of his ceramics sculptures in simplicity such a classic Chinese song. These ceramic art forms emphasize particularly more on the creative concept. Especially his build ceramic babies "century baby" to showing his creativity, talent, and ability. Figure 5 is a sculpture by Yao Yong Kang.

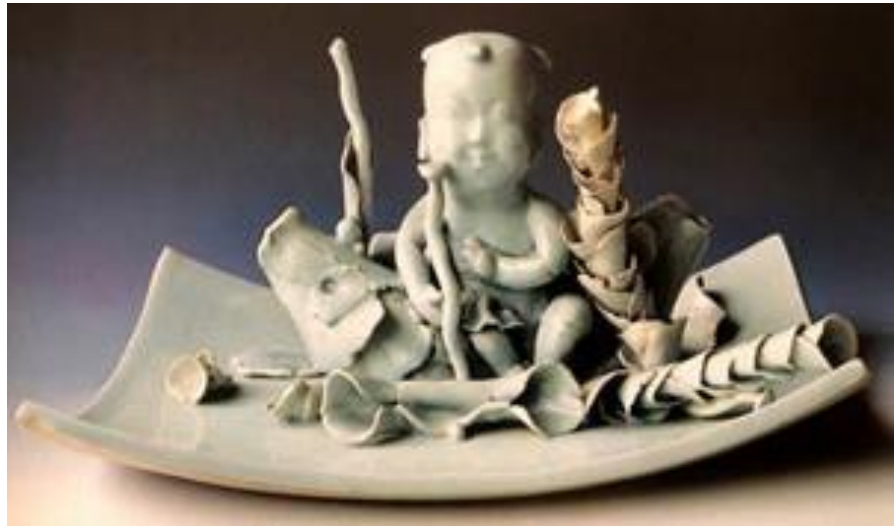

Fig. 5. Artist Yao Yong Kang's Sculpture

\subsubsection{Pei Xu Li}

Artist Pei Xu Li was born in 1958 in Beijing. He graduated from the Jingdezhen ceramics academy. At present, he is a teacher in Suzhou arts and crafts vocational and technological school and director of the ceramic art studio. In the current science and technology era, Chinese people continue to attach great importance to the aesthetical pleasures and traditional forms. That is why we can see Pei Xu Li sculptures beauty is about Chinese architectural styles. Pei Xu Li uses ceramics to investigate the elements of ambiguity and the dynamic of opposites. Uncertainty is expressed by exploring the ratio between forms, textures, and colors. Figure 6 is a sculpture by Pei Xu Li.

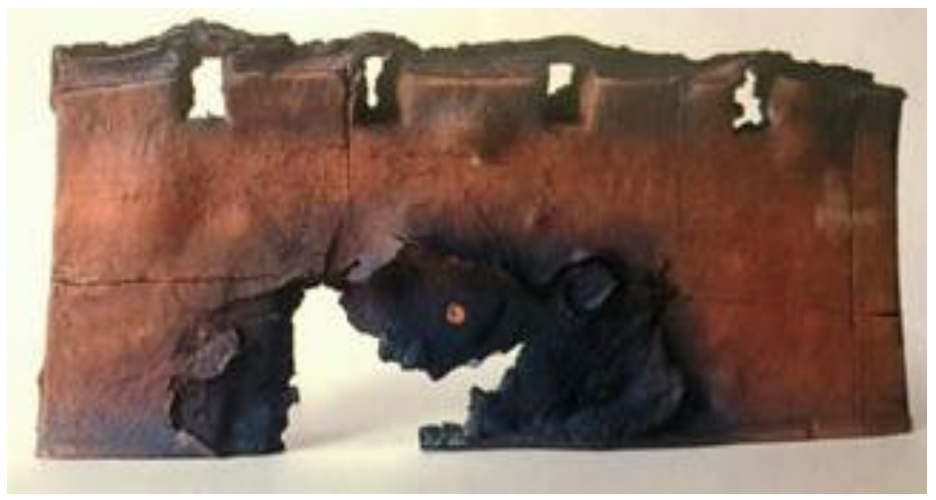

Fig. 6. Artist Pei Xu Li’s Sculpture

\subsubsection{Ah Xian}

Ah Xian was born in Beijing in 1960 and moved to Sydney at the age of 12. He builds on tradition while innovative sculptures and aesthetics in the ceramic tradition. He takes inspiration from his life experience to create works that merge east and West. He has produced a series of half-length human portraits using ancient Chinese techniques such as porcelain. The bust is part of a picture of a traditional Western figure; Ah Xian makes the designs look like tattoos on his figures' skin, making a statement about the indelibility of one's cultural background. Its design is derived from the traditional Chinese decorative design. These are unique ceramic cultures in China. Ah Xian often uses his bust of family members, including his wife, brother, and father, to add a vivid cobalt blue glaze to the traditional sculpture design and share it with everyone. The subject of his ceramic sculpture, known for his artistic sense and aesthetics value, is the decoration on sculpture. Figure 7 is a sculpture by $\mathrm{Ah}$ Xian. 


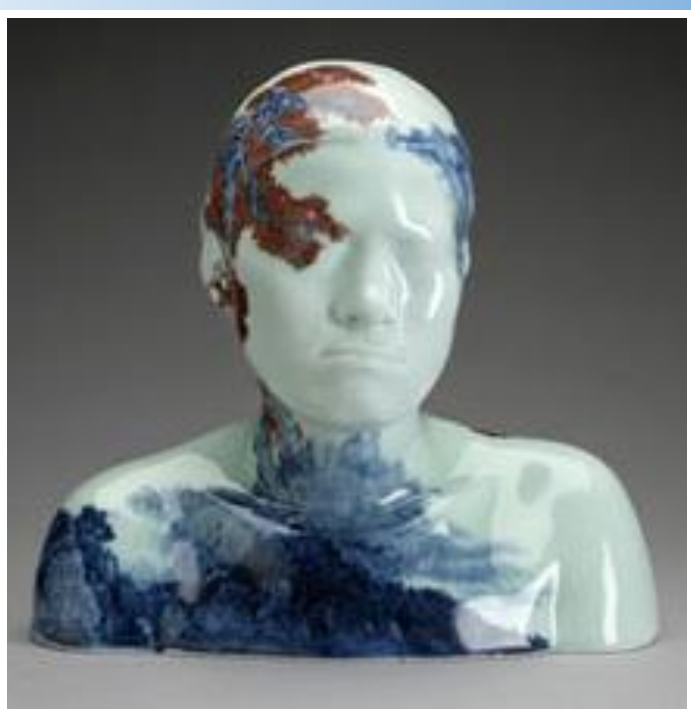

Fig. 7. Artist Ah Xian’s Sculpture

\subsubsection{Lu Bin}

$\mathrm{Lu} \mathrm{Bin}$ is one of the most notable names of a contemporary ceramic sculptor in China. He is born in 1961s in Beijing, China. Currently, he is appointed as a professor at Nanjing University of the Arts. $\mathrm{He}$ is working with porcelain clay. The glaze is no use for his works because he is never interested in building glossy clay sculptures. His sculptures concept is about ancient Chinese ceramic history and fossils. Through his artworks, he wants to show the present society the importance of minerals. The different aesthetic and unique color effect that's the reason his artworks is different from others. Figure 8 is a sculpture by Lu Bin.

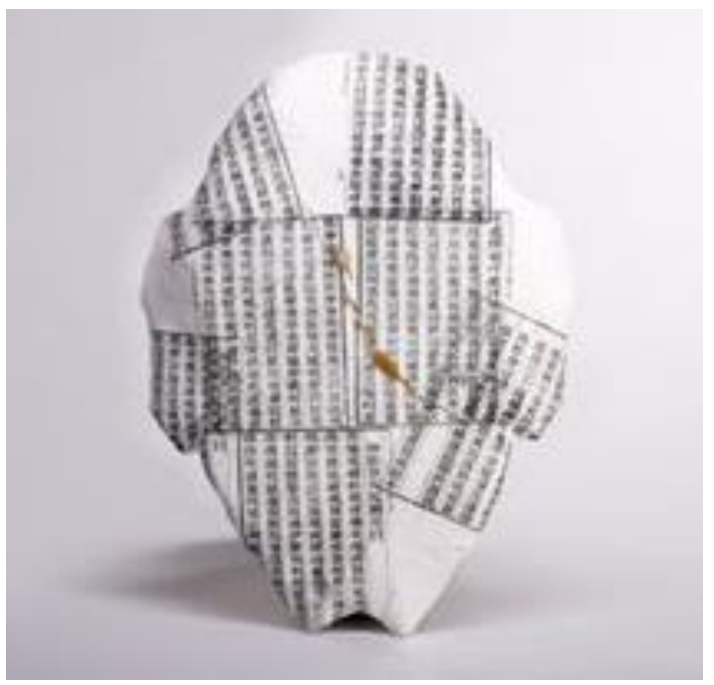

Fig. 8. Artist Lu bin's Sculpture

\subsubsection{Lu Pinchang}

Eminent ceramic artist Lu Pinchang was born 1962 in Shangrao, Jiangxi Province, China. Since childhood, he interested in painting, the influence of his father and elder brother, in 1982, after he graduated concentration to the development of contemporary art in China. Artist Lu Pinching started research into the traditions of Chinese classic art and folk art. He has enjoyed significant benefits from folk art. He always tries to create unique textures and surface effects on folk forms. His made ceramic sculptures series "Ah Fu," "Impressions of China," "Historical Landscape" is particularly significant. Figure 9 is a sculpture by Lu Pinchang. 


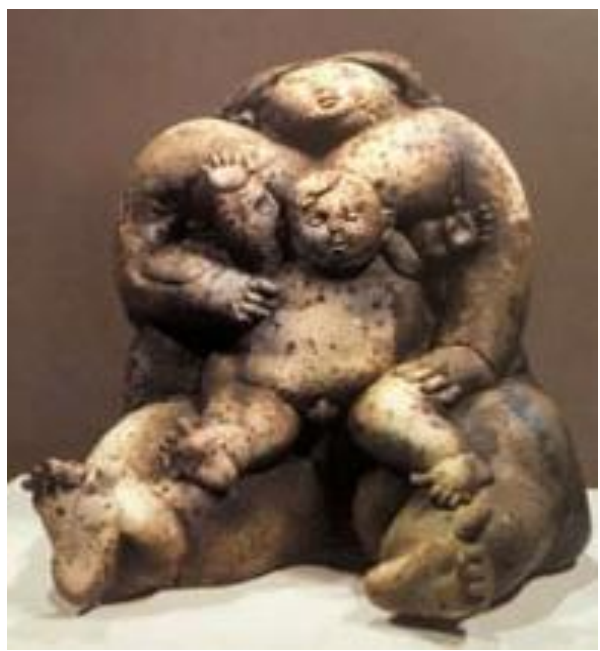

Fig. 9. Artist Lu Pinchang's Sculpture

\subsubsection{Bai Lei}

Ceramic artist Bai Lei was born in 1963 at Jiangxi Province. Now he is a professor at the art college of Suzhou University. He has presented abstract shapes in his artworks. In his ceramic sculptures, we can see the unique texture. The philosophy behind his ceramic sculpture is a process of relaxing the artist's mood. He believes that for making art, clay is the material that has a relation with nature. Figure 10 is a sculpture by Bai Lei.

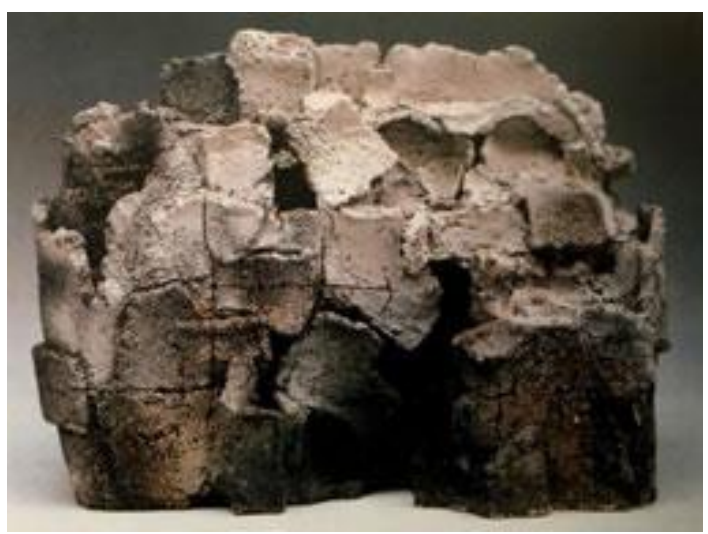

Fig. 10. Artist Bai Lei’s Sculpture

\subsubsection{Bai Ming}

Bai Ming is one of the most famous contemporary ceramic artist and painter born in September 1965 in Yugan, Jiangxi Province of China. Now he is director of the Department of Ceramic Art in the Academy of Arts and Design of Tsinghua University. Bai Ming has contributed to the revival of contemporary Chinese ceramics and introduced it to a new worldwide audience through numerous exhibitions. Today he is arguably China's greatest exponent of this most traditional art form. We can see his ceramics works represent glorious images and the artist's own words: his ceramics art form and process was showing varieties of color just like Chinese characters. Figure 11 is a sculpture by Bai Ming.

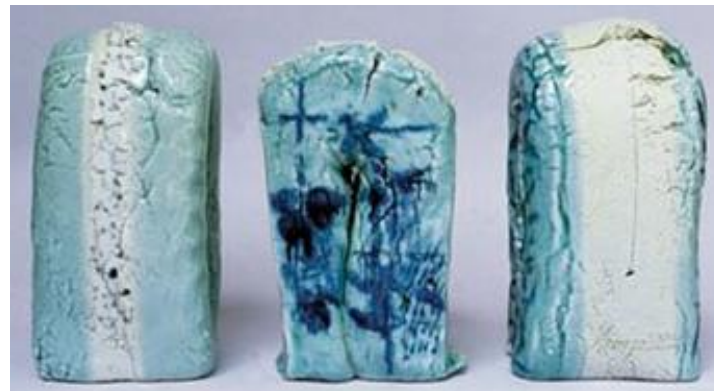

Fig. 11. Artist Bai Lei’s Sculpture 


\subsubsection{Jiang Yan}

Jiang Yan is one of the excellent contemporary ceramic artists in China. Jiang Yan did her Ph.D. in 2000, and Jiang Yan is a member of the international ceramic association. At present, she worked as an associate professor at Nanjing University of the Arts. Her ceramic works are different from usually what we see on art. The ceramic sculptures made by her are a unique reflection of aesthetic thought. She creates a ceramic sculpture is a combination of cups, pot, plates with the human figures. It looks like a diverse functional with artistic form. Using bone China clay makes it more complicated, light, and luxurious. Another group of the same title works uses titanium-plated gloss gives stylish and cool looks. Her new series "City Landscape" seems to be working with the viewer to discuss the fundamental philosophical issues that are how to fusion in the forming natural and artificial speed, clean and purify the environment. This series of works used geometric patterns to give her works a unique look. Figure 12 is a sculpture by Jiang Yan.

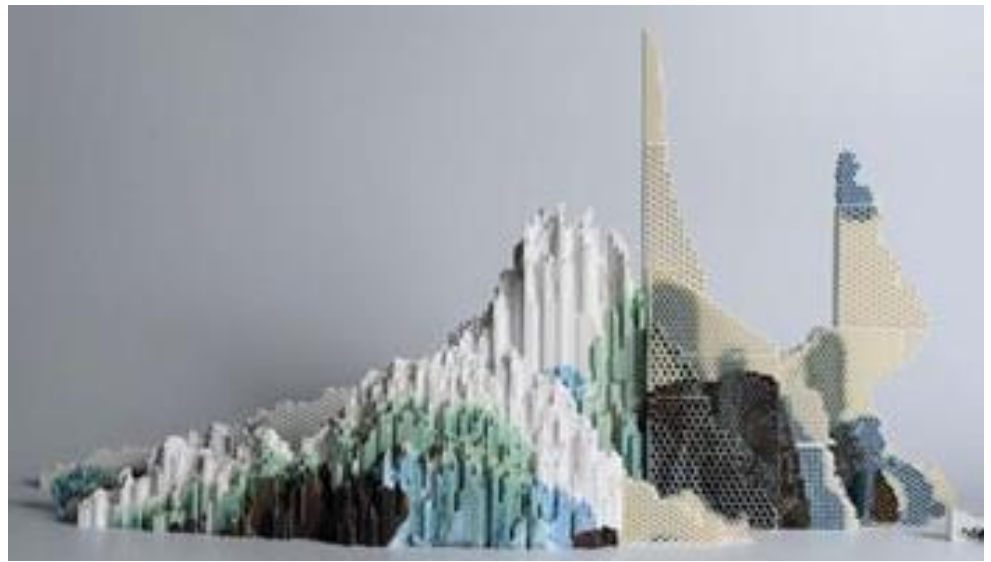

Fig. 12. Artist Jiang Yan's sculpture

\subsection{Bangladesh Contemporary Ceramic Sculptors and their Artworks}

\subsubsection{Alok Ray}

Artist Alok Ray is the proponent of contemporary modern Sculpture in Bangladesh. He was born in 1950. His sculptures open a new landscape of the ceramic field in Bangladesh. Alok Ray used most of his time to make large-sized sculptures. The ceramic sculpture he created contains contemporary social and political messages. The sizeable ceramic head made by Alok Ray also shows the condition of the poor. Alok Ray is a humanitarian warrior by using sculpture as a medium of his struggle. His three-dimensional works using terra sigillata and Lead Glaze add new dimensions to the history of contemporary ceramic sculpture. Primitive expressive portraits predominated in his sculpture. In 1981 exhibits different levels of ceramic sculpture show 'crying of the soil' created on the contemporary political subject. Presumably, this ceramic exhibition gave a widespread path to our practicing of the ceramic field of Bangladesh. His designed sculptures are decorating at several sculpture parks across the outside of the country, on his ceramic sculptures using a unique glaze color effect given a new look. It can be said that the ceramic sculpture created by him is the beginning of the progress of the contemporary ceramic sculptures of Bangladesh. Figure 13 is a sculpture by Alok Ray.

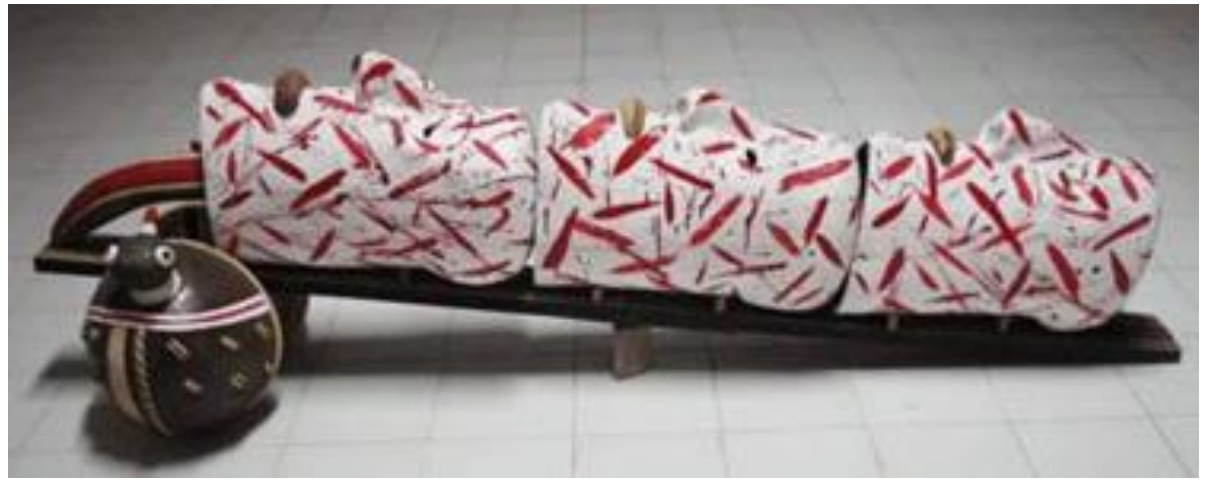

Fig. 13. Artist Alok Ray’s Sculpture 


\subsubsection{Dr. Azharul Islam}

Artist Dr. Azharul Islam was born in Netrokona in 1970. From student life, he has been sincerely practicing various mediums of ceramic and very earnestly praised for practicing Terracotta, mosaic, studio pottery, ceramic Sculpture. Now Azharul Islam is an associate professor of the department of the ceramic University of Dhaka. At different times, he had a keen desire to create sculptures on various subjects. So, therefore, Azharul Islam had broken traditional pottery rules to designed contemporary ceramic sculptures. The contents of the ceramic sculpture he made are familiarity issues around us. For example- Bangladeshi farmers, fish, birds, animals, etc. He constructs in the form of ceramic sculptures in cubic form. This artist used red clay to translate content into abstract forms. Such a large-scale artwork 'tension.' He created contemporary installation artwork with countless rats made by earthenware clay. In his exploration of the new, he presents the complexity of the journey of social life in the artist's art practice. On the other hand, absorbing emotions on social issues, he created sculptures on the adjectives of pure happiness. Just a few years ago, he made lots of ceramic sculptures about the bull. In these artworks, he presented the bull's strength, energy, and speed. He made the pure form of the cave painting visible in his contemporary ceramic sculptures. Artist Dr. Azharul Islam is an inspiration to the next generation of Bangladeshi ceramic artists. Figure 14 is a sculpture by Dr. Azharul Islam.

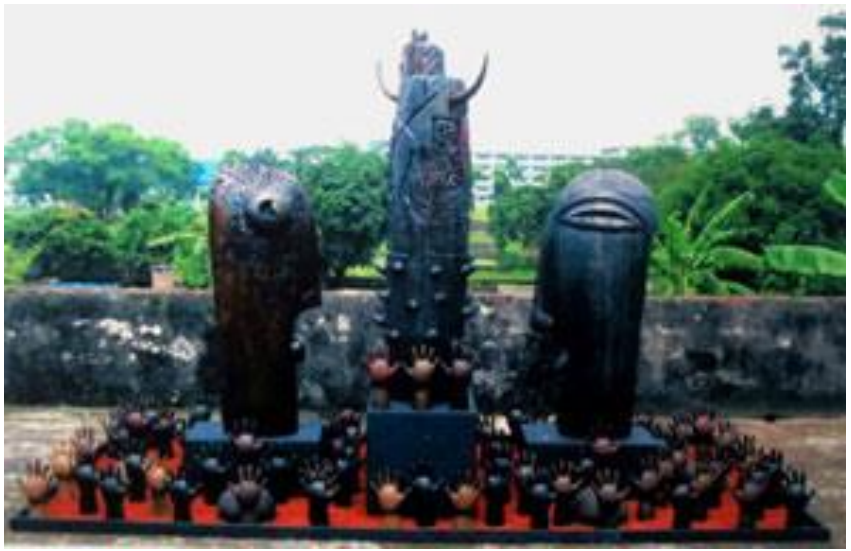

Fig. 14. Artist Dr. Azharul Islam's Sculpture

\subsubsection{Debases Pal}

Debases Pal is a renowned name in Bangladesh's contemporary ceramic sculptor at the time. He was born in 1971 in Mymensingh. At present, he is an associate professor of the department of the ceramic University of Dhaka. He was awarded the grand national award (Bangladesh Shilpakala Academy Award) in 2017. Artist debases pal following traditional pattern on his works and represents as own style. In his works, he added different levels of contemporary ceramic sculpture. His works have presented 1952-language movements, 1971-liberation war, social and political issues. He created his artwork with the passion and sophisticated knowledge of modern education. His addition to the aesthetic aspects of each works and also successfully researched on glaze is Bangladeshi ceramics sculpture has taken one step forward. Figure 15 is a sculpture by Debases Pal.

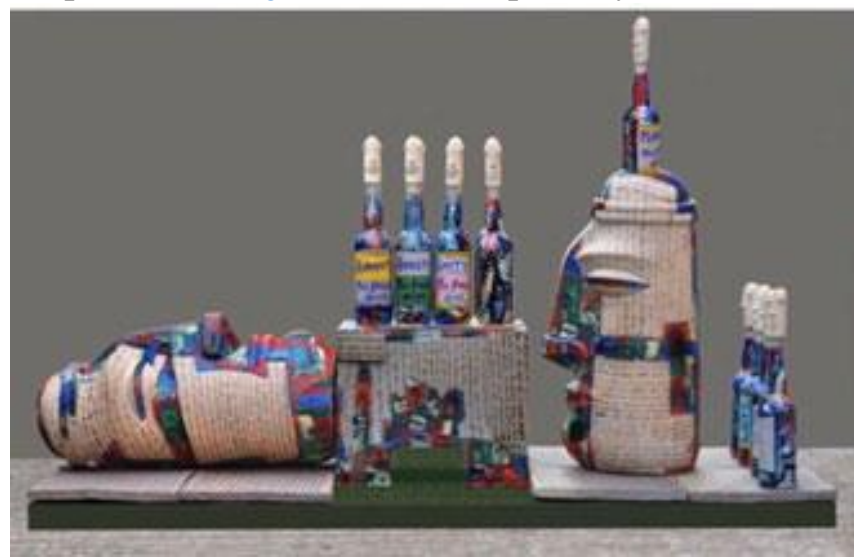

Fig. 15. Artist Debases pal's Sculpture 


\subsubsection{Robiul Islam}

Artist Robiul Islam is an essential name of the contemporary ceramic Sculpture of Bangladesh. He was born in 1974 in Jessore. Now he is an associate professor of the department of the ceramic University of Dhaka. In his ceramic work, presenting and expressing the subject is sufficient to introduce aesthetics and artistry into art. After researching the soil in many ways, he created ceramic sculpture in a simple form of his style. He used clay slab to builds contemporary ceramic sculptures. This artist gives more importance to the thematic than medium. His work can sometimes be seen as a variation of form, and sometimes with a variety of glaze and color. Figure 16 is a sculpture by Robiul Islam.

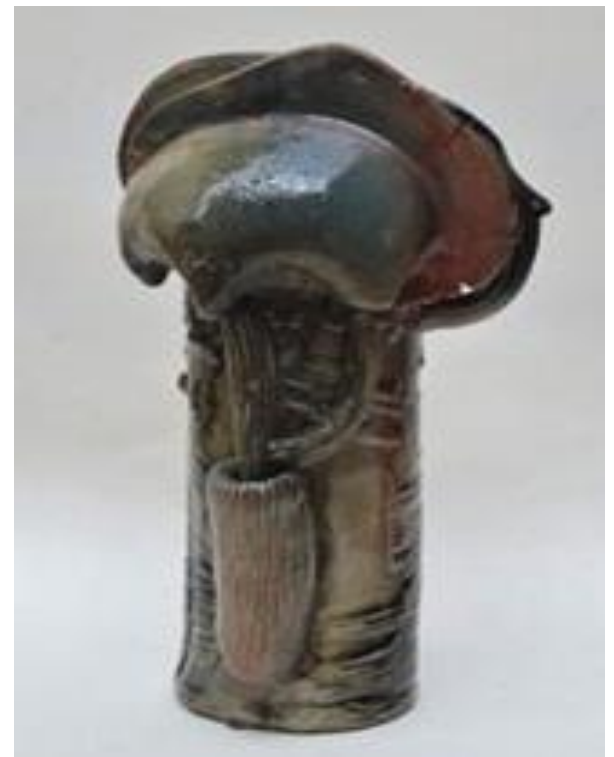

Fig. 16. Artist Robiul Islam's Sculpture

\subsubsection{Sameena M. Karim}

Sameena M. Karim is one of the brilliant female sculptors in Bangladesh. Sameena M. Karim graduated from the Institute of Fine Arts of Chittagong University in 1994. She has been running an art gallery named 'Mrinmoy Art Gallery' since 1998. Sameena M. Karim is currently holding the post of Director of Emkay Enterprise and the General Secretary of Chittagong Sculpture Centre. She conducts courses on Graphic Arts and Sculpture in different universities in Chittagong, such as CUET and Premier University. Sameena M. Karim has received many awards from various institutions as recognition for her works. In her artworks, she is using modern folk motifs. Her art content is mother and child and man and woman in harmony or fusion. Sometimes it plays like a musical crescendo imbued with love and embrace. She always creates a slab building ceramic sculptures. Just pressing with her fingers turned the clay into a creative sculpture where one side folk style and another side, we can see three-dimensional contemporary sculptures. The folk concept of her art introduces us to the country and nation in a new way. Figure 17 is a sculpture by Sameena M. Karim.

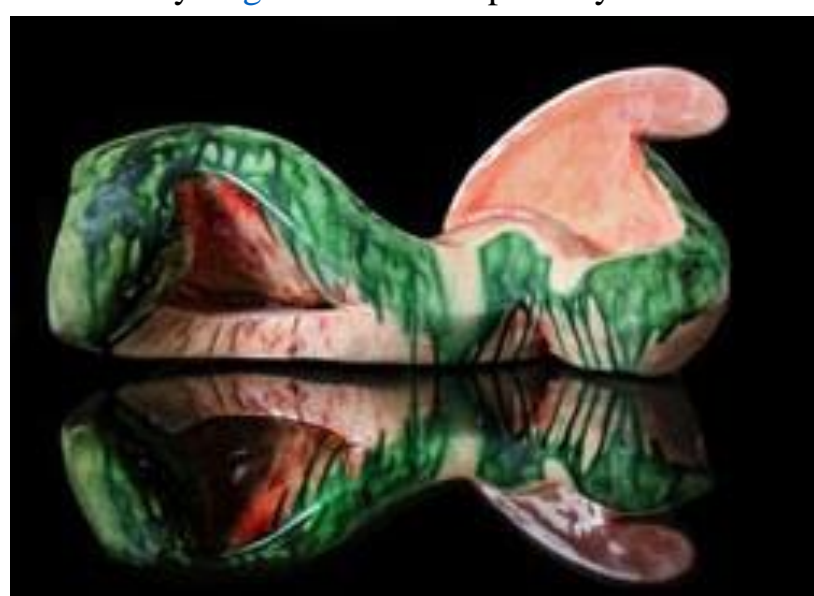

Fig. 17. Artist Sameena M. Karim's Sculpture 


\subsection{Similarities and Differences between Contemporary Chinese and Bangladeshi Ceramic Sculptures}

\subsubsection{Based on Aesthetic}

Along with social, political, economic changes, there are many changes, improvement, amplification, additions of art. Through new experiments, the techniques have become more diverse, more impressive, and more beautiful. Every nation and country has its unique beauty, which indirectly places a vital role in the aesthetics of art. Basically, in Bangladesh, ceramic products are much used in daily life, but objects of clay are now taking a more prominent place in over ascetic lives. The simplicity of Bangladeshi contemporary ceramic sculptures makes imperative and immensely powerful. The female beauty of emphasis on the construction of Bangladeshi figurative sculpture is in the sizeable curvy breast; the waist is like a long neck of a swan, large fleshy buttocks, etc. Which is not a reflection of the real, somewhat surreal than real. However, Chinese figurative ceramic sculptures are quite different. Figurative works converted from realism are at their most characteristic in Chinese sculpture. In the previous chapters we analyzed, contemporary ceramic artist works are show more abstract and observe the manifestation of the expressionist theory. The emergence of expressionist theory, in the field of contemporary ceramic art, triggered a radical change in the art of ceramic sculpture.

This present day, with the extremely bloom civilization, ceramic sculpture creation has also absorbed the postmodern style, spit the limits of modernism. I think continuously new Bangladeshi culture and development of the ceramic sculptures processing are continually giving new objects to ceramic aesthetics. Contemporary ceramic aesthetics cannot be divided from the spread of life aesthetic and environmental aesthetics, but modern ceramic aesthetics is still rooted deeply in the traditional Bangladeshi culture. In this matter, I can figure out the similarity is that Chinese contemporary ceramic sculptures aesthetic is deeply rooted in Chinese traditions and customs. After generation hard work, Chinese contemporary ceramic creation is entering a period of changing, not only the changing of old artists and new artists but also artistic sense, aesthetic standard, and creative idea.

\subsubsection{Culture Influence}

Sculptures are a part of every culture. It represents the visualization and creative motives of the people. When an artist creates sculpture, sometimes the artist enters his culture. What does culture mean? Culture includes habits, clothing, music, dance, language, food, abilities, and practices, etc. Which always influences the work of art. I think that China and contemporary Bangladeshi Sculpture also affect one's perspective on understanding sculpture. If we look back at the past and the cultural evolution in ceramics, is the histories transform how we imagine today, how we practice as artists, and how we even instruct the new generation? I think the culture has an important role to play in improving society. Throughout history, Chinese art was never isolated from outside influences. Bangladesh occupied by the British for more than 200 years, so we have little impact on British culture. As a result, the art has its effect. In Bangladeshi culture, have boundaries openly exhibited nude figures sculptures. Bangladeshi and Chinese people live in a specific cultural circumstance. It is impossible to avoid the cultural and social ideals of the two countries that had many things in common because Bangladesh and China are located on the continent of Asia. In the field of ceramic sculptures, both countries have a productive historical position.

The improvement of ceramic sculpture art is inalienable from the progress of social, culture \& economic growth. In the field of ceramic sculptures, contemporary ceramic artists represented by Lu Bin, Lu Pinchang are continually exploring the development of cultural and humanism of ceramic materials in the context of contemporary ceramic sculpture. Similarly, the contemporary artists I have seen in Bangladesh are working with Debases pal and Sameena M. Karim. Chinese contemporary ceramic sculpture has proficient the new cultural movement. Contemporary ceramic artists are expressing culture through ceramic sculptures. In the composition of modern ceramic sculptures has its standard. This change of introspection, the refinement of learning, will only begin when the elevated element needs human societies are met, and the height of civilization reaches a wealthy level. In today's society, ceramic sculptures as a creative practice have slowly shown its more and more significant character in humans' cultural and artistic life. It is said that ceramic sculpture art organizes certain living conditions of culture and is one of the most consequential outside visual blooming of social and cultural beauty. 


\subsubsection{The Importance of Ingredients}

Clay is the essential first thing in making a ceramic object which we collect from nature. I think china clay is a blessing from nature for china, and chicness ceramic artists have appropriately utilized. At present, when we created contemporary ceramic sculpture is required not only vast knowledge about art but also the necessary raw materials are critical. There is a shortage of these raw materials in Bangladesh. After researching ceramics in china for almost three years, I think the raw material that Chinese artists use to create contemporary ceramic sculptures may not be enough, but sufficient. However, in Bangladesh, it is difficult to find many raw materials, especially Glaze material. That is making a significant impact in creating contemporary ceramic art in Bangladesh. If we compare that the main ingredient is the soil - China has porcelain, there are different colored clays like "zisha" clay from Yixing. Without using any glaze after firing, the shiny light effect comes that is made of a ceramic object by this clay. It is truly incomparable. However, the Terracotta that is made of redcolored clay in Bangladesh has its beauty. The white clay present in Bangladesh is a type of clay located in the middle. This central white clay can be used to create ceramic sculpture with a maximum temperature is $1200^{\circ} \mathrm{C}$. However, some Chinese contemporary artists created artworks to used porcelain or bone China, whose temperature is much higher around $1350^{\circ} \mathrm{C}$.

The process of creating contemporary ceramic sculptures between Bangladeshi and Chinese artists there also has technical differences. The technology that Chinese contemporary artists use to create sculptures is much better than use the technique of contemporary artists in Bangladesh. Even in the universities that teach using machinery from that point of Bangladesh's modern ceramic is far behind. Compared to Bangladesh, china has advanced in kiln technology. It is vital to know about firing to make ceramic objects. For example, artist Chen Song xian experiments with fire and glaze of contemporary ceramic sculptures. Contemporary ceramic artists have built a new system to produce artifice in their creations with the help of modern instruments. However, there are many problems with material and advanced technology. Still, I can say with pride Bangladeshi artists have given particular importance to contemporary ceramic sculpture making, which is a critical contribution internationally. A few in the hand of artists have been continually working to create modern ceramic sculptures in Bangladesh. There are always innovations in the use of glaze, and various tests Bangladesh is renowned for its contemporary ceramic Sculpture.

\subsubsection{Philosophical Impression}

Philosophy has multiple various meanings, but philosophy is a particular system of beliefs, values, and ethics. The amount of art is necessarily connected with philosophical impression. Undoubtedly, the contemporary ceramic sculptures explore highly individualized philosophy which influences by humanity, nationality, and faith. The regular pursuit of creating ceramic sculptures and idealistic skills certainly requires artists to observe philosophical things that are around them. In Bangladesh, the majority of the population is Muslim. Islam is vital in social and cultural aspects. Despite being a Muslim majority, the State shall ensure equal status and equal rights in the practice of the Hindu, Buddhist, Christian, and other religions. Another thing to say about Bangladeshi art \& culture is the Baul philosophy, especially Lalon Shah, the famous Bengali mystic. His poetic imagination picture a worldview critical of religious chauvinism. Lalon may have associated the official Bangladeshi heritage respect today [52].

A sense of aesthetics from the perspective of Chinese philosophy is something unique. Confucianism, for example, is the main philosophy of the socialism movement in China, which also contributes to the artistic life of sculpture. Confucianism is a flow of belief that can build a mix of aesthetics and culture in aesthetic functions and achievements. The aesthetic and ethical are so nearly connected in pragmatic were improving the human condition through philosophy. In other words, that philosophy firmly attached to china's politics. Chinese people believe the federal government cannot be achieved without self-government. According to Laozi, someone who loves his body more than the empire can be given custody of the empire [53]. Indeed philosophies are improving our humanism and social beauty. The quality of Yao Yongkang's contemporary ceramic art in "century baby" is compatible with the concept of contemporary ceramic art in the earth. Still, it has subjective in Chinese ceramic art, and China has its multiplication. While Practicing Philosophy explores some of the different ways that pragmatists and religions practiced the beautiful Bangladeshi life, there is also comparable variety in Chinese thought. In the present era of globalization, change is more critical. It raises ceramic creation to join the structure of Bangladeshi and Chinese culture with contemporary art 
from an open and construction outlook. The hopeful convergence between modern concepts and traditional Chinese ceramic material could perhaps grow a new transcultural global ceramic philosophy of art.

\section{Conclusion}

China and Bangladesh ceramics have played a more critical role in social life in contemporary situations. Moreover, to improve our experience of ceramic sculpture does not just mean build up our happiness and understanding of artworks. For art is not only a source of personal pleasure, but art is also an effective way of giving love and beauty to the social activities of everyday life. The Chinese contemporary ceramic artist expresses their physical beauty and form beauty, and Bangladeshi contemporary ceramic artist also shows their personal feeling and subjective well. Today the china is leading and day by day blooming in the ceramic field, tomorrow Bangladeshi ceramic may acquire unprecedented success. We need to realize how Chinese ceramic sculpture became what it is, and to view the ways followed by the Chinese philosophy of ceramic art. The combination of contemporary china and Bangladeshi ceramic sculpture is so touching and unique. AAt this point, the emphasis put forward in this study is if the structure of knowledge in modern ceramic art can make global ceramic artists useful to society. Through a variety of experiments and creative learning, the future of ceramic sculpture will be brighter and subject-based innovative ceramic sculpture creation.

\section{References}

[1] C. Bautze-Picron, "Gautam Sengupta and Sharmila Saha, Vibrant Rock: A Catalogue of Stone Sculptures in the State Archaeological Museum, West Bengal," South Asian Stud., vol. 31, no. 1, pp. 157-158, Jan. 2015, doi: 10.1080/02666030.2015.1008822.

[2] S. Sen, "The Transformative Context of a Temple in Early Medieval Varendri: Report of the Excavation at Tileshwarir Aara in Dinajpur District, Bangladesh," South Asian Stud., vol. 31, no. 1, pp. 71-110, Jan. 2015, doi: 10.1080/02666030.2015.1008813.

[3] B. Karmakar and I. Gupta, "Tracing the Impact of Krishnalila Narratives on Bengal Temple Architecture: A Study of Terracotta Temples of Baranagar," J. Herit. Manag., vol. 3, no. 1, pp. 49-70, Jun. 2018, doi: $10.1177 / 2455929618773274$.

[4] B. B. Sarma, "A Brief Study of Heritage Issues in Bangladesh, with Special Reference to Dhaka City," SSRN Electron. J., 2009, doi: 10.2139/ssrn.1433682.

[5] S. Pierson, "The Movement of Chinese Ceramics: Appropriation in Global History," J. World Hist., vol. 23, no. 1, pp. 9-39, 2012, doi: 10.1353/jwh.2012.0013.

[6] I. Gaskell, "Spilt Ink: Aesthetic Globalization and Contemporary Chinese Art," Br. J. Aesthet., vol. 52, no. 1, pp. 1-16, Jan. 2012, doi: 10.1093/aesthj/ayr052.

[7] N. R. Kalita, "The Art of Re-Interpreting Self: Self Imagery in the Works of Indian Artists," Int. J. Vis. Perform. Arts, vol. 1, no. 2, pp. 69-79, Nov. 2019, doi: 10.31763/viperarts.v1i2.52.

[8] C. Nadelman, "Pot People Recent Figurative Ceramic Sculpture," Sculpt. Rev., vol. 59, no. 3, pp. 18-23, Sep. 2010, doi: 10.1177/074752841005900303.

[9] K. Zhang, "Constitution Study on the Application of Chinese Character Elements in Modern Ceramics," in Proceedings of the 3rd International Conference on Art Studies: Science, Experience, Education (ICASSEE 2019), 2019, doi: 10.2991/icassee-19.2019.66.

[10] L. Pittwood, "The headless woman in contemporary Chinese art," J. Contemp. Chinese Art, vol. 1, no. 1, pp. 65-82, Mar. 2014, doi: 10.1386/jcca.1.1.65_1.

[11]G. Gowlland, "Style, Skill and Modernity in the Zisha Pottery of China," J. Mod. Cr., vol. 2, no. 2, pp. 129-141, Jul. 2009, doi: 10.2752/174967809X463079.

[12]P. S. Quinn, S. Zhang, Y. Xia, and X. Li, "Building the Terracotta Army: ceramic craft technology and organisation of production at Qin Shihuang's mausoleum complex," Antiquity, vol. 91, no. 358, pp. 966979, Aug. 2017, doi: 10.15184/aqy.2017.126.

[13]P. B. Vandiver and S. A. Vasil'ev, “A 16,000 Year-Old Ceramic Human-Figurine from Maina, Russia,” MRS Proc., vol. 712, p. II6.9, Mar. 2002, doi: 10.1557/PROC-712-II6.9. 
[14] Y. V Kuzmin, J. A. Timothy Jull, and G. S. Burr, "Major Patterns in the Neolithic Chronology of East Asia: Issues of the Origin of Pottery, Agriculture, and Civilization,” Radiocarbon, vol. 51, no. 3, pp. 891903, Jul. 2009, doi: 10.1017/S0033822200033968.

[15]L. Jin, "A Comparative Study on the Material Application of Traditional Sculpture and Contemporary Sculpture," in Proceedings of the 2017 7th International Conference on Social Network, Communication and Education (SNCE 2017), 2017, doi: 10.2991/snce-17.2017.176.

[16]H. Su, "Analysis of the Relationship between Modern Sculpture and Ecological Harmony," in Proceedings of the 2015 International Conference on Management, Education, Information and Control, 2015, doi: 10.2991/meici-15.2015.184.

[17] M.-A. Mace and T. Ward, "Modeling the Creative Process: A Grounded Theory Analysis of Creativity in the Domain of Art Making," Creat. Res. J., vol. 14, no. 2, pp. 179-192, Apr. 2002, doi: 10.1207/S15326934CRJ1402_5.

[18] G. Harbottle and L. Holmes, "The History of the Brookhaven National Laboratory Project in Archaeological Chemistry, and Applying Nuclear Methods to the Fine Arts," Archaeometry, vol. 49, no. 2, pp. 185-199, May 2007, doi: 10.1111/j.1475-4754.2007.00295.x.

[19] L. Nickel, "The First Emperor and sculpture in China," Bull. Sch. Orient. African Stud., vol. 76, no. 3, pp. 413-447, Oct. 2013, doi: 10.1017/S0041977X13000487.

[20] J. Rawson, "Inside out: creating the exotic within early Tang dynasty China in the seventh and eighth centuries," World Art, vol. 2, no. 1, pp. 25-45, Mar. 2012, doi: 10.1080/21500894.2012.662171.

[21]R. O. Lopes, "Securing the Harmony between the High and the Low: Power Animals and Symbols of Political Authority in Ancient Chinese Jades and Bronzes," Asian Perspect., vol. 53, no. 2, pp. 195-225, 2014, doi: 10.1353/asi.2014.0019.

[22] N. S. Steinhardt, "The Tang Architectural Icon and the Politics of Chinese Architectural History," Art Bull., vol. 86, no. 2, p. 228, Jun. 2004, doi: 10.2307/3177416.

[23]F. Du and B. Su, "Further study of sources of the imported cobalt-blue pigment used on Jingdezhen porcelain from late 13 to early 15 centuries," Sci. China Ser. E Technol. Sci., vol. 51, no. 3, pp. 249-259, Mar. 2008, doi: 10.1007/s11431-008-0013-0.

[24]E. C. Huang, "From the Imperial Court to the International Art Market: Jingdezhen Porcelain Production as Global Visual Culture," J. World Hist., vol. 23, no. 1, pp. 115-145, 2012, doi: 10.1353/jwh.2012.0028.

[25] T. Zhu, H. Huang, H. Wang, L. Hu, and X. Yi, "Comparison of celadon from the Yaozhou and Xicun kilns in the Northern Song Dynasty of China by X-ray fluorescence and microscopy," J. Archaeol. Sci., vol. 38, no. 11, pp. 3134-3140, Nov. 2011, doi: 10.1016/j.jas.2011.07.017.

[26]P. Shi, F. Wang, Y. Wang, J. Zhu, B. Zhang, and Y. Fang, "Coloring and translucency mechanisms of Five dynasty celadon body from Yaozhou kiln,” Ceram. Int., vol. 43, no. 15, pp. 11616-11622, Oct. 2017, doi: 10.1016/j.ceramint.2017.05.334.

[27]P. A. Schroeder and G. Erickson, "Kaolin: From Ancient Porcelains to Nanocomposites," Elements, vol. 10, no. 3, pp. 177-182, Jun. 2014, doi: 10.2113/gselements.10.3.177.

[28]B. Gulzhan, M. Tolkyn, and S. Raikhan, “Kublai Khan's Role in the Cultural Development of the Yuan Empire,” Procedia - Soc. Behav. Sci., vol. 122, pp. 24-28, Mar. 2014, doi: 10.1016/j.sbspro.2014.01.1297.

[29]A. Gerritsen, "Porcelain and the Material Culture of the Mongol-Yuan Court," J. Early Mod. Hist., vol. 16, no. 3, pp. 241-273, 2012, doi: 10.1163/157006512X644793.

[30] Y. Qu, J. Xu, X. Xi, C. Huang, and J. Yang, "Microstructure characteristics of blue-and-white porcelain from the folk kiln of Ming and Qing Dynasties," Ceram. Int., vol. 40, no. 6, pp. 8783-8790, Jul. 2014, doi: 10.1016/j.ceramint.2014.01.100.

[31] M. I. Dias, M. I. Prudêncio, M. A. Pinto De Matos, and A. L. Rodrigues, "Tracing the origin of blue and white Chinese Porcelain ordered for the Portuguese market during the Ming dynasty using INAA," $J$. Archaeol. Sci., vol. 40, no. 7, pp. 3046-3057, Jul. 2013, doi: 10.1016/j.jas.2013.03.007. 
[32]H. Duan, X. Zhang, B. Kang, G. Wang, L. Qu, and Y. Lei, "Non-destructive Analysis and Deterioration Study of a Decorated Famille Rose Porcelain Bowl of Qianlong Reign from the Forbidden City," Stud. Conserv., vol. 64, no. 6, pp. 311-322, Aug. 2019, doi: 10.1080/00393630.2019.1617589.

[33] Y. Li et al., "Study of arsenic in Famille rose porcelain from the Imperial Palace of Qing Dynasty, Beijing, China," Ceram. Int., vol. 44, no. 2, pp. 1627-1632, Feb. 2018, doi: 10.1016/j.ceramint.2017.10.084.

[34]J. Miao, B. Yang, and D. Mu, "Identification and Differentiation of Opaque Chinese Overglaze Yellow Enamels by Raman Spectroscopy and Supporting Techniques*," Archaeometry, vol. 52, no. 1, pp. 146155, Feb. 2010, doi: 10.1111/j.1475-4754.2009.00466.x.

[35]B. N. Prasad, "Votive Inscriptions on the Sculptures of Early Medieval Samatata-Harikela, Bengal: Explorations in Socio-religious History," Relig. South Asia, vol. 4, no. 1, Feb. 2011, doi: 10.1558/rosa.v4i1.27.

[36] L. R. Selim, “On the possibility of cultural property: the Musée Guimet controversy and case study of events in Bangladesh,” J. R. Anthropol. Inst., vol. 17, pp. S176-S191, May 2011, doi: 10.1111/j.14679655.2011.01695.x.

[37] A. Datta, "Through the eyes of an artist: consumption ethos and commercial art in Bengal," J. Hist. Res. Mark., vol. 10, no. 3, pp. 242-261, Aug. 2018, doi: 10.1108/JHRM-03-2018-0014.

[38] P. Ghosh, "Tales, Tanks, and Temples: The Creation of a Sacred Center in Seventeenth-Century Bengal," Asian Folkl. Stud., vol. 61, no. 2, p. 193, 2002, doi: 10.2307/1178971.

[39]H. P. Ray, "Buddhist Monuments Across the Bay of Bengal: Cultural Routes and Maritime Networks," TRaNS Trans -Regional -National Stud. Southeast Asia, vol. 7, no. 2, pp. 159-180, Nov. 2019, doi: 10.1017/trn.2018.17.

[40] R. Thapar, "The Mauryan empire in early India*," Hist. Res., vol. 79, no. 205, pp. 287-305, Aug. 2006, doi: 10.1111/j.1468-2281.2006.00394.x.

[41] G. Bhattacharya, "Trio of Prosperity: A Gupta Terracotta Plaque from Bangladesh," South Asian Stud., vol. 12, no. 1, pp. 39-47, Jan. 1996, doi: 10.1080/02666030.1996.9628508.

[42] S. Panja, "Monuments in a flood zone: 'builders' and 'recipients' in ancient Varendri, (Eastern India and Bangladesh),” Antiquity, vol. 77, no. 297, pp. 497-504, Sep. 2003, doi: 10.1017/S0003598X00092553.

[43] W. K. Bain, "Bishnupur: A Town of Cultural Excellence," J. Anthropol. Surv. India, vol. 65, no. 1, pp. 89-105, Jun. 2016, doi: 10.1177/2277436X20160107.

[44] S. Ahmed, ""Mosque Architecture" Or Architecture of Mosque: A New Notions of Bengal During the Muslim Rule,” J. Islam. Archit., vol. 4, no. 1, p. 1, Jun. 2016, doi: 10.18860/jia.v4i1.3167.

[45] J. Edwards, "Introduction: From the East India Company to the West Indies and Beyond: The World of British Sculpture, c . 1757-1947," Vis. Cult. Br., vol. 11, no. 2, pp. 147-172, Jul. 2010, doi: 10.1080/14714781003784280.

[46] G. Michell, "Enamul Haque: Bengal sculptures: Hindu iconography up to c. 1250 A.D. 584 pp. Dhaka: Bangladesh National Museum, 1992. Taka 750, \$40.,” Bull. Sch. Orient. African Stud., vol. 56, no. 1, pp. 158-159, Feb. 1993, doi: 10.1017/S0041977X00002020.

[47] G.-M. Yang and T. Suchan, "The Cultural Revolution and Contemporary Chinese Art," Art Educ., vol. 62, no. 6, pp. 25-32, Nov. 2009, doi: 10.1080/00043125.2009.11519042.

[48] T. Zhang, "Chinese Strategic Culture: Traditional and Present Features," Comp. Strateg., vol. 21, no. 2, pp. 73-90, Apr. 2002, doi: 10.1080/01495930290043056.

[49] S. Kharchenkova, "The market metaphors: Making sense of the emerging market for contemporary art in China," Poetics, vol. 71, pp. 71-82, Dec. 2018, doi: 10.1016/j.poetic.2018.06.001.

[50] Y. Chen and L. Zhou, "Reflections on the Development of Contemporary Ceramic Aesthetics," in Proceedings of the 7th International Conference on Education, Management, Information and Mechanical Engineering (EMIM 2017), 2017, doi: 10.2991/emim-17.2017.388.

[51] T. H. B. Sofield and F. M. S. Li, "Tourism development and cultural policies in China," Ann. Tour. Res., vol. 25, no. 2, pp. 362-392, Apr. 1998, doi: 10.1016/S0160-7383(97)00092-3. 
[52] S. S. Roy and R. Hassan, "Voicing Our Roots: A Critical Review of Indigenous Media and Knowledge in Bengal," in Indigenous Knowledge and Learning in Asia/Pacific and Africa, New York: Palgrave Macmillan US, 2010, pp. 179-193, doi: 10.1057/9780230111813_12.

[53]Z. Weijie and A. Saiping, “The Concept of 'Body' in Lao Zi,” Int. J. Soc. Sci. Humanit., pp. 13-16, Feb. 2019, doi: 10.18178/ijssh.2019.V9.982. 